\title{
Studying the Effect of the Atmosphere Factors on Properties of the Panel and Thin Film which are used as Luminescent Solar Concentrators and Made from the Tagetes Flowers
}

\author{
Alaa Mahdi Mohammed \\ University of Kufa, Faculty of Science, Dep. of Physics, P.O.Box (21), Kufa, Najaf, Iraq
}

\begin{abstract}
In this study, panel and film had been prepared from organic pigment extraction from flower Tagetes as luminescent solar concentrators to improve the conversion efficiency of solar cells. The absorption and fluorescence of this extracted pigment is relatively, good. It has a considerable ability to absorb a high quantity from the sun light. Throughout this study, each of the panel and thin film has considered with constant concentration and thickness, and the use of epoxy polymer in the preparation of the panel and the alcohol acetone is considered constant, too, that they do not affect the properties of the panel and thin film coat with the solar cell. Effects of atmosphere factors (wind, dust, temperature, and sunlight intensity) on the properties of the panel and thin film with the solar cell have been investigated. The results show that both of the panel and thin film contributed to raise up the efficiency of the solar cell. It has been found that increasing the intensity of light increases the solar cell efficiency at a high rate. Conversely, the heat factor, effectively, lowers the solar cell efficiency (adversely proportioned). However, factors of the wind and dust did not greatly affect the properties of the panel and thin film of solar cell.
\end{abstract}

Keywords: panel, thin, film, luminescent, solar, cell, Tagetes, concentrator

\section{Introduction}

It is known that, light is emitted from various optical sources, primarily visible sunlight, and that this visible light is a form of large energy [1]. The solar panel is used for fluorescence generation, through the conversion of light energy rather than thermal energy into electrical or thermal energy, and the resulting energy is renewable natural energy which is environment-friendly clean [2]. What distinguishes the new technology for the manufacture of solar cells is that the use of organic pigments and thus there was no need to silicon material. In this study, Tagetes flower have been chosen for their orange color to be used in the extraction to get organic pigments. The study, also, aims to investigate the effect of atmospheric factors on panel and thin film properties, which are used as solar concentrator and made from the Tagetes flowers

\section{Tagetes Flower with Orange Color}

The common name in English, "marigold" is derived from "Mary's gold". It is also known by the Verbally as Al-Jaafari. The florets had been many uses, of which to color human foods [3]. Molecular formula $\left(\mathrm{C}_{40} \mathrm{H}_{52} \mathrm{O}_{2}\right)$ and Molar mass (568.88 gm.mol-1), physical- orange colored slightly hydroscopic crystalline solid [4]. It gives a fluorescent orange pigment when it dissolves in alcohol. The formula structure and form of Tagetes flower show in figure (1):

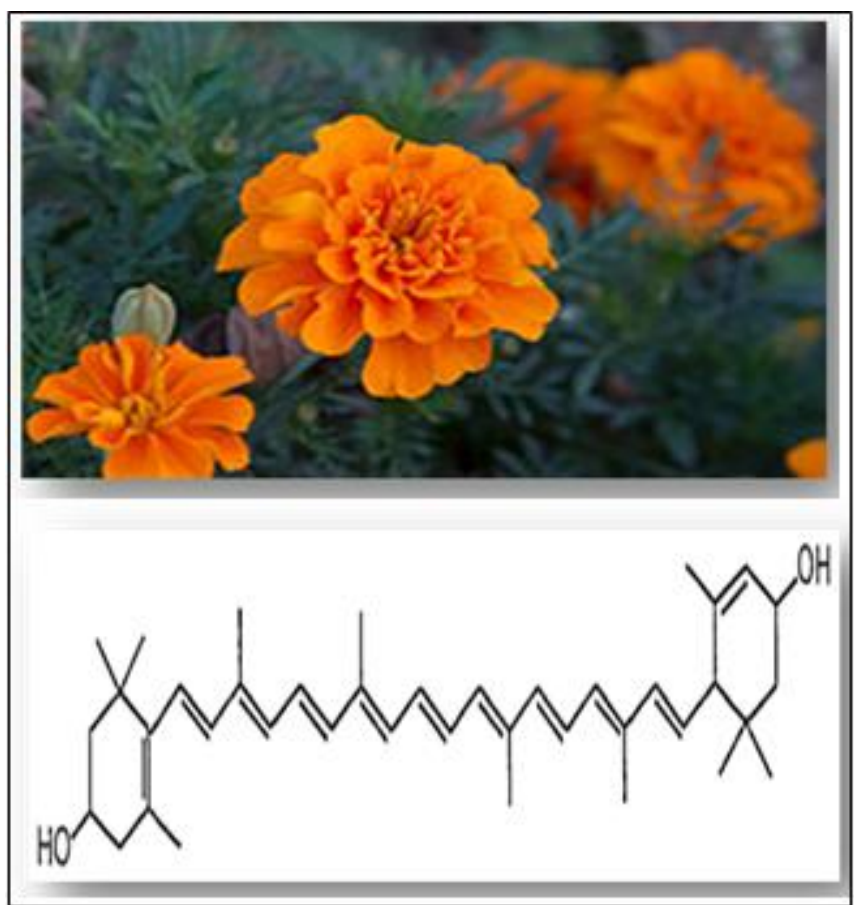

Figure 1: Form of Tagetes flowers and formulas structure [4]

\section{Experimental Details}

\subsection{Sample extraction}

Groups of leaves of Tagetes flower with (orange) color have been taken and cleaned by water wash, then dried out of water and weight by the electronic balance. The leaves, then, left for several days to turn into dry leaves. After dried, they made as powder and weight using electronic balance, too. Acetone has been used as solvent for extraction of pigment. 


\section{International Journal of Science and Research (IJSR) \\ ISSN (Online): 2319-7064}

Index Copernicus Value (2015): 78.96 | Impact Factor (2015): 6.391

A20 $\mathrm{ml}$ of Acetone alcohol added to the powder of the Tagetes flowers and thoroughly mixed. After the mixing, samples from solution were taken for analysis by the centrifuge at $(7,000) \mathrm{rpm}$ for $(10 \mathrm{~min})$. The samples were then put at $20^{\circ} \mathrm{C}$ for two nights in the dark to allow for maximum diffusion of phenolics from the cellular matrix [5]. After that, the samples were subjected to analysis using the nomination paper. Accordingly, from the extracted Tagetes flower, solution of pigment with (orange) color have been prepared.

\subsection{Quantity measurement for pigment extract from Tagetes flower by measuring the absorbance body paragraphs}

It has been found that, the concentration of this extractive pigment solution can be done following equation (1) as [6]:

$\mathrm{C}=20.2$ (absor. at 645$)+8.02$ (absor. at 663$) *(\mathrm{~V} / 1000 *$ $\mathrm{W})(1)$

Where:

$\mathrm{C}$ : concentration of the pigment

$\mathrm{V}$ : volume of extract last to the pigment

$\mathrm{W}$ : weight soft to the plant

The concentrations of this pigment are $(2.34 \times 10-2) \mathrm{mg} . \mathrm{g}-1$.

\subsection{Measurement of the Fluorescence and Absorption spectra for pigment extractive:}

The absorption and fluorescence spectra for the pigment extractive are shown in figures (2) and (3). The pigment extractive has absorption intensity increases with a little shifting towards higher wavelengths while concentration is constant. Fluorescence maximum value is shown by the fluorescence curves that deviate to the red-Stokes shift with concentration constant.

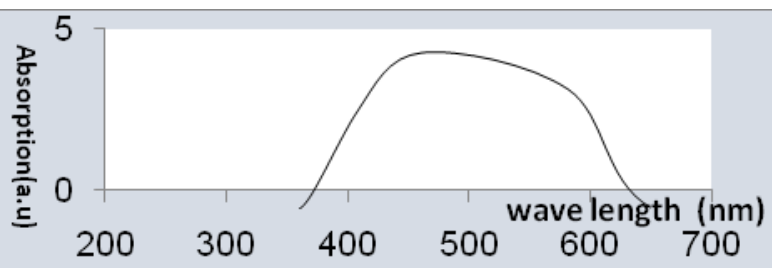

Figure 2: Spectrum absorption for pigment extractive of $(2.34 * 10-2) \mathrm{mg} . \mathrm{g}-1$

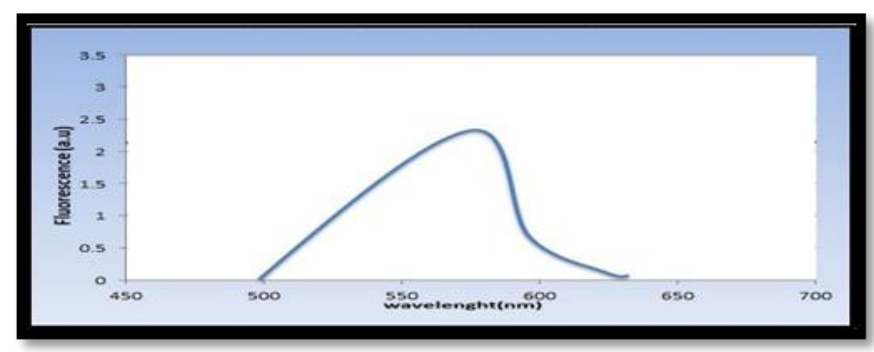

Figure 3: Spectrum fluorescence for pigment extractive of (2.34*10-2) mg .g-1

Lab work of this study showed that absorption spectrum of Acetone alcohol is negligible within the spectral range (450$800) \mathrm{nm}$ of pigment extractive as illustrated in figure (4).

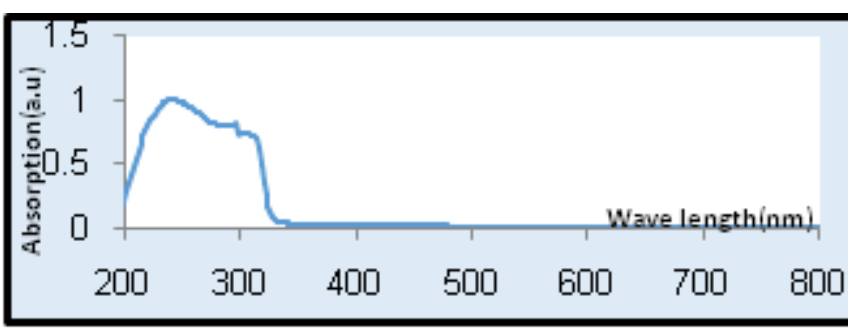

Figure 4: Absorption spectrum of Acetone alcohol

The absorption curve showed in figure(4)of the solvent Acetone became nearly zero at wavelength after $(350 \mathrm{~mm})$. This is an evidence that solvent used do not affect the absorbance of pigment extractive, it is used in this work to solve powder of the Tagetes flower only.

\subsection{Preparation of the panel and thin film}

Epoxypolymer used consists of two parts; A and B. Part A is called (resin) and part B is called (hardener).They added to the solvent of pigment extractive to make panel. The mixing of the two parts should be (2:1) ratio for (2) minutes of mixing [7], and then pigment extractive solvent added to the mix of resin and hardener in order to be mixed together for (3) minutes. After that, the mixture is poured in a glass mold and left for 48 hours at room temperature $\left(25 \mathrm{C}^{\mathrm{o}}\right)$.In preparation of the thin film, there is no need for the polymer epoxy to be added to the pigment solvent, because of method of coating the permian where precipitation pigment solvent on the museembrane glass by technique spin coater (VTC) . Figure (5) shows the panel and thin film as luminescent solar concentrators prepared.

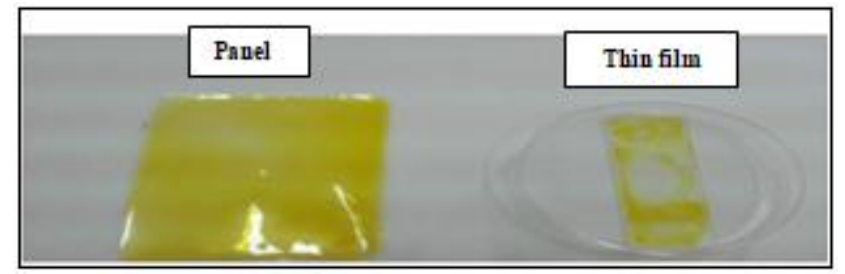

Figure 5: Panel and thin film luminescent solar concentrators prepare

\subsection{Instruments and equipment used}

The instruments and equipment of taking measurements in the laboratory included: the computer, (Panel \& film) which are made of pigment extractive solution for Tagetes flower, light source, thermal source, thermometer, quantity of dust , electric fan, mono crystalline silicon solar cell type $(\mathrm{F}-$ TNY 1180) square - shaped, dimensions 75 X $75 \mathrm{~mm}$ that efficiency as ( $\eta$ : 4.190\%), a digital thermometer measures the temperature of air, liquids, solids, or surfaces electronically [8], the digital electronic caliper and solar module analyzer. Figure (6) shows the instruments and equipment used.

A digital electronic caliper is instrument used to measure the (thickness) of the panel and thin film[9].The solar module analyzer brand prove 200 equipped with PROVA instruments INC company was used to measure the parameters of solar cell efficiency, voltage and current [10]. 
International Journal of Science and Research (IJSR)

ISSN (Online): 2319-7064

Index Copernicus Value (2015): 78.96 | Impact Factor (2015): 6.391

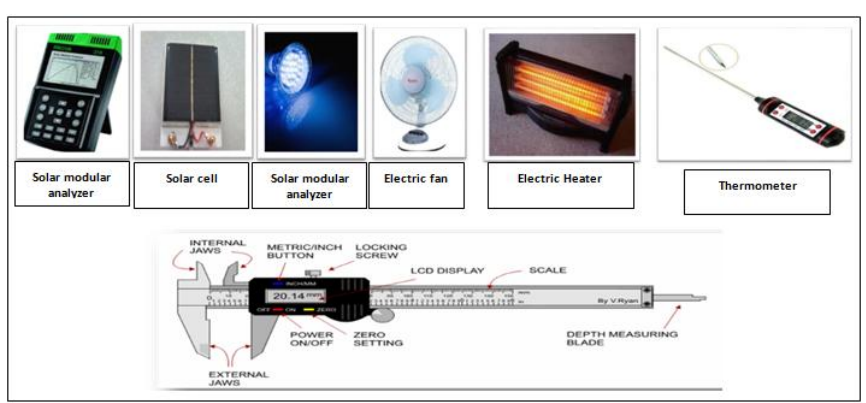

Figure 6: Instruments and equipment used in measurements

\section{Results and Discussion}

When putting the panel or thin film on the solar cell the efficiency $(\eta)$ is increase. The two figures (7) and (8) show the efficiency $(\eta)$ of solar cell with panel and thin film:

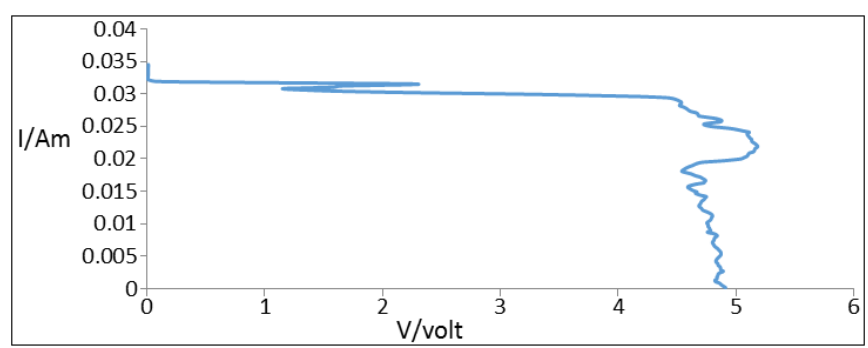

Figure 7: The efficiency $(\eta)$ of solar cell with panel

\subsection{Light intensity factor}

By using light source of (density flux 550 watt $/ \mathrm{m} 2$ ) in the laboratory [11], and falling on the panel for pigment extractive with constant distance $(80 \mathrm{~cm})$ between the light source and solar cell, the module analyzer show measures the efficiency $(\eta)$ and I - V current - voltage to the solar cell, the efficiency $(\eta)$ increased from $(5.272)$ to $(13.86 \%)$. The light when falling on thin film, the efficiency $(\eta)$ increased from $(5.388)$ to $(15.28 \%)$, with rise in the values of current voltage. Figures (9) and (10) show the current - voltage curves for solar cell using the panel and thin film for pigment extractive of Tagetes flower with falling light.

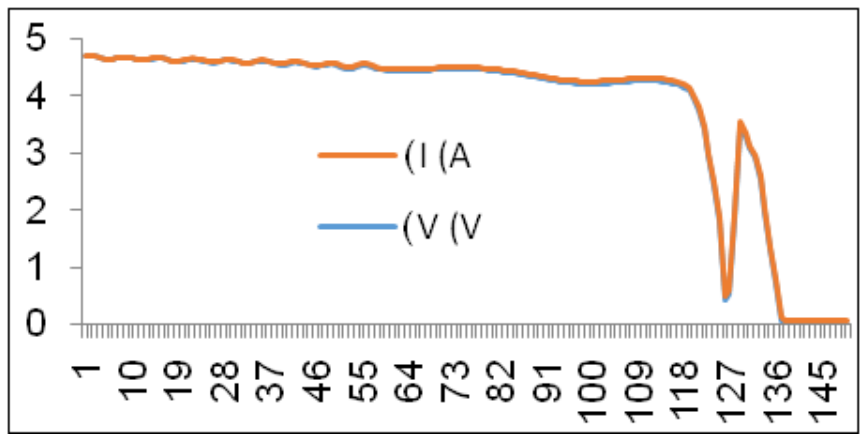

Figure 8: The efficiency $(\eta)$ of solar cell with thin film

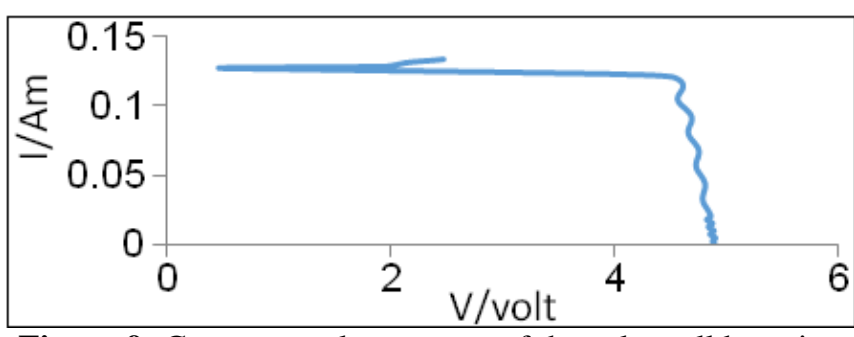

Figure 9: Current - voltage curve of the solar cell by using panel with light factor

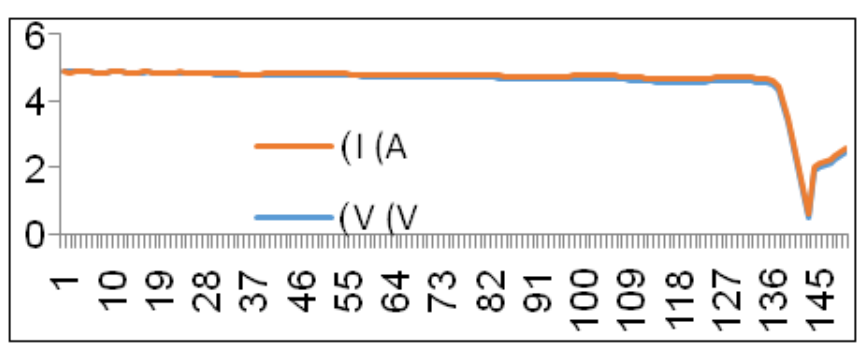

Figure 10: Current - voltage curve of the solar cell by using thin film with light factor

\subsection{Wind intensity factor}

When the air shed by using electric fan of velocity second degree $(1120 \%)$ on the panel with removing the light source away, the efficiency $(\eta)$ of solar cell decreases at $(4.280 \%)$. Also, the thin film decreases efficiency $(\eta)$ at $(4.374 \%)$ for the same conditions. The figures (11) and (12) show current voltage curves for solar cell when using the panel and thin film with shed of wind intensity.

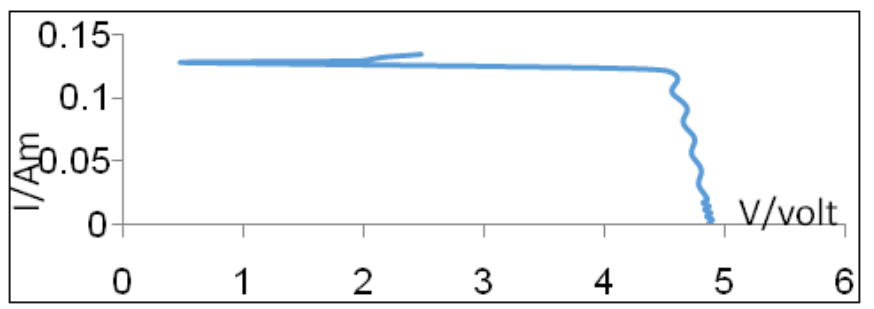

Figure 11: Current - voltage curve of the solar cell by using panel with wind factor

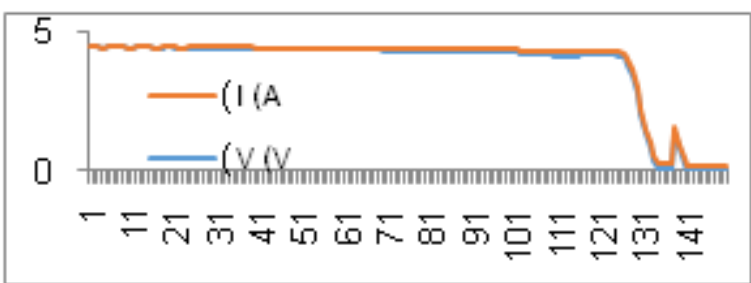

Figure 12: Current - voltage curve of the solar cell by using thin film with wind factor

\subsection{Temperature factor}

By using the thermal source to increase temperature from (27 to 31$)^{\circ} \mathrm{C}$ on the panel, the efficiency $(\eta)$ of solar cell dropped to $(3.514 \%)$. Also, for the thin film dropped to (4.374\%). The figures (13) and (14) show current-voltage curves for solar cell by using the panel and thin film, respectively, with shed heat of them. 
International Journal of Science and Research (IJSR)

ISSN (Online): 2319-7064

Index Copernicus Value (2015): 78.96 | Impact Factor (2015): 6.391

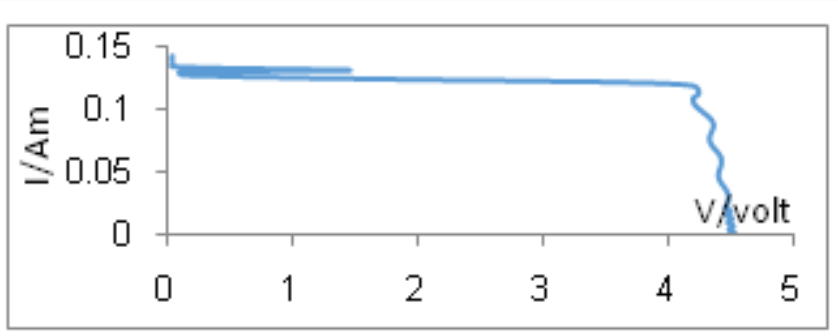

Figure 13: Current - voltage curve of the solar cell by using panel with heat factor

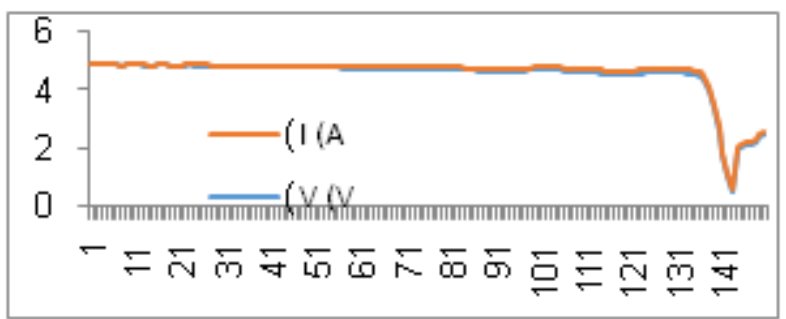

Figure 14: Current - voltage curve of the solar cell by using thin film with heat factor

\subsection{Dust factor}

Dust spread on the panel has been investigated, It reduced a little portion $(5.955 \%)$ of solar cell efficiency $(\eta)$. Also, with the thin film the efficiency $(\eta)$ dropped by $(4.242 \%)$. The figures (15) and (16) show current-voltage curves of the solar cell by using the panel and thin film, respectively, with shed quantity of dust.

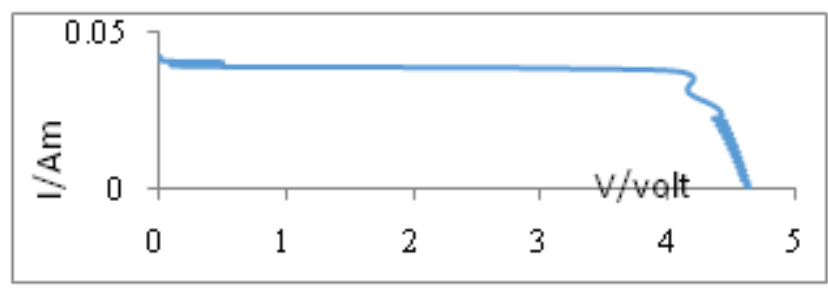

Figure 15: Current - voltage curve of the solar cell by using panel with dust factor

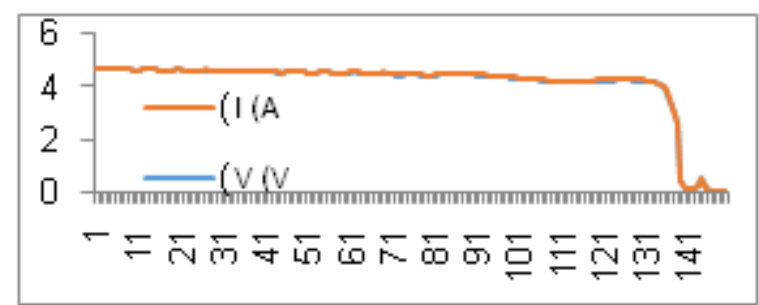

Figure 16: Current - voltage curve of the solar cell by using thin film with dust factor

Collectively, Table (1) lists the values of the efficiency (1) for the solar cell when putting the panel and thin film for pigment extractive with one concentration. Table (2) list the

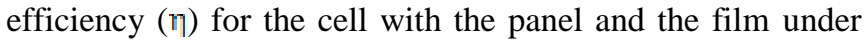
effect of each of the Factors: Light intensity, Wind, Temperature and Dust.
Table 1: The solar cell efficiency by using the panel and thin film for pigment extractive of Tagetes flower

\begin{tabular}{|c|c|c|c|}
\hline Sample & Concentration $\left(\mathrm{mg.g}^{-1}\right)$ & Thickness $(\mathrm{mm})$ & $\eta \%$ \\
\hline Panel & $2.34 \times 10^{-2}$ & 1.15 & 5.955 \\
\hline Thin film & $2.34 \times 10^{-2}$ & 0.297 & 5.388 \\
\hline
\end{tabular}

Table 2: The solar cell efficiency with panel and thin film for pigment extractive of Tagetes flower under effect of factors; Light intensity, Wind, Temperature and Dust

\begin{tabular}{|c|c|c|}
\hline Factor & Panel $\eta \%$ & Thin film $\eta \%$ \\
\hline Light intensity $\left(\mathrm{w} / \mathrm{m}^{2}\right)$ & 13.86 & 15.28 \\
\hline Wind & 4.280 & 4.374 \\
\hline Temperature & 3.514 & 3.992 \\
\hline Dust & 5.292 & 5.242 \\
\hline
\end{tabular}

It is clear from Table (2) and Figures (9) and (10) that, the highest efficiency obtained for the solar cell with the panel and thin film when the light is falling with intensity of (550 watt/ r) on both the panel and thin film as a constant distance $(80 \mathrm{~cm})$ between the solar cell and the light source. The increase in the efficiency of solar cell reflected on rising up the values of both current and voltages.

Back to Table (2) and Figures (13) and (14), efficiency of the solar cell with the panel and thin film dropped when heat on the panel and thin film increased from (27) to (31) ${ }^{\circ} \mathrm{C}$, and the values of both current and voltages also dropped. Similarly, it can be noticed from Table (2) and the figures $(11,12,15$ and 16), the wind and dust factor has affected the solar cell by a slight decrease in its efficiency, this indicates that the efficiency of the solar cell panel and thin film does not affect much under the conditions of dust and wind. It is clearly listed in Table (1) that the concentration of the pigment solution is considered constant and relatively low. The thickness is quite different between the panel and thin film.

\section{Conclusions}

- The pigment which is extracted is a good pigment, because it has a high fluorescence and absorption in the visible region.

- Acetone is a good solvent to Tagetes flowers.

- The panel and thin film of the pigment extractive from Tagetes flower raises the efficiency of the solar cell.

- The panel and thin film of pigment extractive with low concentration are good and preferably need low concentrations in the preparation of panels and thin films.

- The light intensity factor with the panel and thin film of pigment extractive increases the efficiency of the solar cell, while the heat factor adversely affects the efficiency.

- The pigment extracted in this study can be used as one or two layers in the multilayer solar cell.

\section{References}

[1] Mohammed D. Rubin and Ahmad Yusuf, "General Physics", ninth edition, 2014.

[2] Falah Hausen Araby "Study the effect of three factors on the output parameters of silicon solar cell", MSc. Thesis, Babylon University, Iraq, 2006. 


\section{International Journal of Science and Research (IJSR) \\ ISSN (Online): 2319-7064}

Index Copernicus Value (2015): 78.96 Impact Factor (2015): 6.391

[3] Jump upB. K. Dutta, S. Karmakar, A. Naglot, J. C. Aich and M. Begam, "Anticandidial activity of some essential oils of a mega biodiversity hotspot in India". Mycoses. 50 (2): 121-124. doi:10.1111/j.14390507.2006.01332.x. PMID 17305775, March 2007.

[4] https://www.mdidea.com/products/herbextract/marigold /data03.html

[5] Joseph MA, Lloyd WR, Ralph DW. "Anthocaynins from black sorghum and their antioxidant properties". Food Chem., 90: 293-301. Kahkonen MP, Hopia AI, Vuorela, 2004.

[6] HJ, Rauha JP, Pihlaja K, Kujala TS "Antioxidant activity of plant extracts containing phenolic compounds". J. Agric. Food Chem., 47: 3954-3962. 1999.

[7] Douglas A. Skoog "Analytical Chemistry" - skoog west Holler Crouch-Michigan state University - U.S.A, 2010.

[8] Kataloic "Polymer of Epoxcy Resin REPCON - IR" Hexion Specialty Chemicals, Inc USA.

[9] Results 1 - 16 of 3684 - Discover Digital Thermometerson Amazon.com,.

[10] Ulrich and Roger B. ,"Roman woodworking", Yale University Press, New Haven, Conn., pp. 52f., ISBN 0300-10341-7, 2007.

[11] Lexin Industrial Development Co. Ltd., "Prova 200 Solar Module Analyzer", Guang Dong, China, (Gatalogs publishedonline, www.diytrade.com/China/pd/4040971/ prova200).

[12] Faiz Salih Abbas "Luminescent solar concentrators to improve solar cell conversion efficiency", MSc. Thesis, College of Science-University of Kufa, 2013.

\section{Author Profile}

Alaa Mahdi Mohammed received the B.S. and M.S. degrees in Physics from University of Kufa at2009 and 2014, respectively. Since 2010she work in Faculty of Science, University of Kufa as lecturing staff member. She has several published articles in the field of optics and solar cells. 